\title{
Chemical induction of larval metamorphosis of Pecten maximus with a note on the nature of naturally occurring triggering substances
}

\author{
Lionel Chevolot ${ }^{1, *}$, Jean-Claude Cochard ${ }^{2}$, Jean-Claude Yvin ${ }^{2, * *}$ \\ ${ }^{1}$ URA CNRS 322, Université de Bretagne Occidentale, 6, avenue Le Grogeu, F-29287, Brest, France \\ ${ }^{2}$ IFREMER, Centre de Brest, B.P. 70, F-29263, Plouzane, France
}

\begin{abstract}
Delayed metamorphosis usually occurs when scallop Pecten maximus (L.) larvae are reared in still water Metamorphosis rates may be increased by adding aqueous extracts of certain marine red algae, including one [Delesseria sanguinea (Linné) Lamouroux (Delesseriaceae, Rhodomelaceae)] from which various chemical inducers have been isolated. Of these, jacaranone (a simple quinol) is by far the most active component; other components ( $p-O H$ phenylacetic acid methyl ester, p-OH benzaldehyde, $p-\mathrm{OH}$ benzyl alcohol) are only weak inducers. All are catabolic derivatives of tyrosine. Homogentisic acid (biosynthetically related to jacaranone) and some catecholamines (LDOPA, epinephrine) can also induce metamorphosis of $P$. maximus larvae. All these compounds can be transformed into quinones by oxidation. This result, together with literature data, strongly suggests that the true inducer(s) present in the environment might possess a quinone or quinone-like structure, as is the case for jacaranone.
\end{abstract}

\section{INTRODUCTION}

Pelagic larvae of many invertebrates continue their planktonic existence in the absence of suitable environmental stimuli, which in many cases have proved to be chemicals. However, very few of these stimuli have to date been unambiguously characterized, owing to difficulties in isolating and identifying them (Kato et al. 1975, Morse \& Morse 1984, Pawlik 1986). Considerable information on this subject has been gathered and reviewed in some recent papers (Burke 1983, Crisp 1984, Morse 1985, 1990, Hadfield 1986).

The shellfish industry's need for a reliable method of recruiting natural bivalve larvae has generated some research. It has long been known that oyster larvae settle preferentially on adult shells, and Crisp (1967) has shown that quinone-tanned proteins of the periostracum are responsible for this effect. In a similar way.

\section{Present addresses:}

- Laboratoire de Biologie Marine, Université de Nantes, 2, rue de la Houssinière, F-44072, Nantes, Cedex 03, France

- Laboratoire GOEMAR, Zac de la Madeleine, B.P. 55, F-35403 Saint Malo, France
DOPA-containing polyphenolic proteins extracted from Mytilus edulis feet enhance the metamorphosis rates of M. edulis larvae (Estupinan \& Waite 1988). Ether extracts of oyster liquor have been also found to stimulate spatfall of the oyster Crassostrea virginica (Keck et al. 1971), and Nielsen (1973) reported that acetazolamide (a carbonic anhydrase inhibitor) enhanced larval settlement of Ostrea lutaria. A pigmented bacterium named LST has also been shown to play a beneficial role in the settling and metamorphosis of Crassostrea virginica larvae. The pigment (melanin), its precursor (L-DOPA), or intermediate metabolites, seem to be responsible for the observed effect (Weiner \& Colwell 1982). Hodgson \& Bourne (1988) also reported that the scallop Chlamys hastata metamorphoses on fouled substrates. Neurotransmitter-like molecules (L-DOPA, epinephrine, norepinephrine) induce settlement in several molluscan species, especially Bivalvia (Cooper 1982, Coon et al. 1985, 1986, Weiner et al. 1985). Subsequently, Coon \& Bonar (1987) showed that adrenergic agonists stimulate metamorphosis, whereas adrenergic antagonists are inhibitors. Indeed it is probable that some of these molecules act upon the larval nervous system rather like an exogenous trigger (Hirata \& Hadfield 1986). Similarly, increasing 
$\left[\mathrm{K}^{+}\right]$concentration induces larval metamorphosis in many marine invertebrate species (Yool et al. 1986) including oysters (Nell \& Holliday 1986); this effect is due to a direct depolarization of sensitive cells (Yool et al. 1986)

To metamorphose, the scallop Pecten maximus (L.) requires no specific substratum (Brand et al. 1980, Minchin 1981), but only a clean surface above the sea bottom where it can escape siltation. In a hatchery, in still water and in the absence of an inducer, $P$. maximus larvae delay metamorphosis for several weeks, after which most individuals die. In running water, metamorphosis occurs, but extends over 1 to 2 wh. We have observed that some red algae can produce molecules able to induce metamorphosis of $P$. maximus larvae. A few years ago (Yvin et al. 1985) we isolated the most active molecule from one of these algae: Delesseria sanguinea (Linné) Lamouroux (Delesseriaceae, Rhodomelaceae). This paper describes the isolation of various active molecules obtained from $D$. sanguinea and the biological assays performed with these constituents, with a biosynthetically related compound (homogentisic acid), and with catecholamines known to induce metamorphosis of oyster larvae *

\section{MATERIALS AND METHODS}

Larval metamorphosis assays. Pecten maximus larvae were raised according to procedures described by Buestel et al. (1982), based on work by Loosanoff \& Davis (1963) and Gruffydd \& Beaumont (1972). For metamorphosis assays, larvae were sorted by screening on a $150 \mu \mathrm{m}$ mesh. Although selected larvae were not necessarily competent, this proved to be the only prac. tical method for this study. Larvae were then suspended in a cylinder for $15 \mathrm{~min}$. Only larvae swimming in the upper two-thirds of the cylinder were used; unhealthy larvae sank and were discarded.

Larval densities were evaluated by counting larvae in 6 samples of 100 ul taken from a 21 homogenized volume (coefficient of variation: $13 \%$ ). All experiments were conducted in a 0.51 beaker filled with $400 \mathrm{ml}$ of $0.45 \mathrm{~km}$ filtered seawater $\left(18^{\circ} \mathrm{C} ; \mathrm{S}=33\right.$ to $\left.34 \%\right)$. In each beaker, 2000 individuals sorted as described above were added. Chloramphenicol was used as an antibiotic $\left(8 \mathrm{mg} \mathrm{l}^{-1}\right)$. The water was changed every other day for the duration of the experiment ( $8 \mathrm{~d}$ ). At the same time, a few $\mathrm{ml}$ of food supplements (Pavlova

\footnotetext{
- These results were presented at 2 symposia (Biologie appliquée à la conchyliculture et l'héliculture, Rennes, France, Aug 31-Sep 5, 1987; First International Marine Biotechnology Conference, Tokyo, Japan, 3-6 Sep 1989), and part has thus been published in the proceedings
}

Iutheri and Isochrysis galbana, 50/50) were added (algal density: 40 cells $\mu^{-1}$ in the rearing water).

The test compounds were prepared as stock solutions $\left(1 \mathrm{~g} \mathrm{l}^{-1}\right)$ in water or an ethanol-water mixture when water solubility was too low. We checked that addition of ethanol alone had no noticeable effect at the same concentration. Larvae were exposed for $48 \mathrm{~h}$ to the test compound. Each control and each concentration was tested, at least in duplicate, in 2 different beakers. After $48 \mathrm{~h}$, larvae were thoroughly washed to remove any trace of the added exogenous substance. At this stage, differences in morphogenesis did not permit a clear distinction between pediveligers and postlarvae. Rearing was therefore continued for $6 \mathrm{~d}$ until postlarvae could clearly be identified by their dissoconch (postlarval shell)

Percentages of larvae and post-larvae living or dead were evaluated by counting 500 individuals from each beaker. One-way analysis of variance was performed on arcsin-transformed data. When a significant $F$-value was obtained, comparisons between the mean values for each treatment were performed using the $Q$ method of Newman \& Keuls at $5 \%$ confidence level (Snedecor \& Cochran 1967).

Extraction procedures. Algae were collected in the vicinity of Brest, France. Only materials without epibionts were used.

Aqueous extract: $60 \mathrm{~g}$ of each fresh alga were carefully washed, ground and suspended in $300 \mathrm{ml}$ of distilled water for $24 \mathrm{~h}$ at room temperature. Solid materials were removed by filtration, and the remaining aqueous solutions were freeze-dried. Yields from the various algae were $3.85 \mathrm{~g}$ (Dilsea carnosa), $1.0 \mathrm{~g}$ (Delesseria sanguinea, Extract A), $2.2 \mathrm{~g}$ (Palmaria palmata), $1.9 \mathrm{~g}$ (Polysiphonia elongata) and $0.66 \mathrm{~g}$ (Lithothamnium calcareum).

Extraction of Delesseria sanguinea by aqueous EtOH: A freeze-dried algal sample ( $563 \mathrm{~g}$ ) was steeped 3 times in $70 \%$ aqueous EtOH. A small aliquot of the combined extract (Extract B) was dried and the residue used for metamorphosis assays.

The remaining extract was evaporated in vacuo to obtain a concentrate which was partitioned between diethyl ether and water The ether extract was dried over sodium sulfate and the solvent evaporated to yield a green gum (Extract D; $3.28 \mathrm{~g} ; 0.6 \%$ ). An aliquot of the remaining aqueous solution (Extract $C$ ) was dried and used for metamorphosis assays.

Fractionation of Extract D. This extract was applied to a Sephadex $\mathrm{LH} 20$ column feluent: $\mathrm{CH}_{2} \mathrm{Cl}_{2} / \mathrm{MeOH}$ $1: 1, v / v)$. The first polymeric brown fraction was discarded, and the following one was evaporated in vacuo $(1.42 \mathrm{~g})$. An aliquot of this fraction (200 mg) was transferred onto 2 preparative TLC (thick layer chromatography) plates $(20 \times 20 \mathrm{~cm}$; Kieselgel HF $254+366$; 
eluent:cyclohexane/ethylacetate 50:50 v/v) and separated into 2 fractions, $E$ and $F$. Both were tested with positive results. Components present in both fractions ( $p$-OH phenylacetic acid methyl ester $1, p$-OH benzaldehyde $2, p-\mathrm{OH}$ benzylic alcohol $3 \underline{a}$ and its ethyl ether $\underline{3 b}$, jacaranone $\underline{4}$; delesserine 5 ) were purified by a multistep procedure including silica-gel column chromatography and semi-preparative reverse-phase HPLC. The structures of $\underline{1}, \underline{2}, \underline{3 a}, \underline{3 b}$ and $\underline{4}$ were established by mass, NMR and IR spectrometry and by comparison with authentic samples (Yvin et al. 1985). Structural studies of delesserine have been previously published (Yvin et al. 1982).

Synthetic compounds. Catecholamines (epinephrine, norepinephrine, L-DOPA) and homogentisic acid of reagent grade were obtained from the Sigma Chemical Co. (St Louis, MO, USA). In one experiment (see 'Results'), homogentisic acid was oxidized by dissolving $1 \mathrm{~g}$ in $1 \mathrm{l}$ of aerated seawater and leaving for 48 $\mathrm{h}$ before being used as a normal stock solution. Synthetic jacaranone was obtained according to a previously described procedure (Yvin et al. 1985).

\section{RESULTS}

\section{Stimulation of larval metamorphosis by algal extracts}

Crude aqueous extracts prepared from 5 red seaweeds (Dilsea carnosa, Palmaria palmata, Delesseria sanguinea, Polysiphonia elongata and Lithothamnium calcareum) were tested for metamorphosis-inducing activity (Fig. 1). Analysis of variance showed a highly significant heterogeneity $\left(F_{11}^{10}=20.36\right)$. The Newman \& Keuls test confirmed a significant increase in metamor-

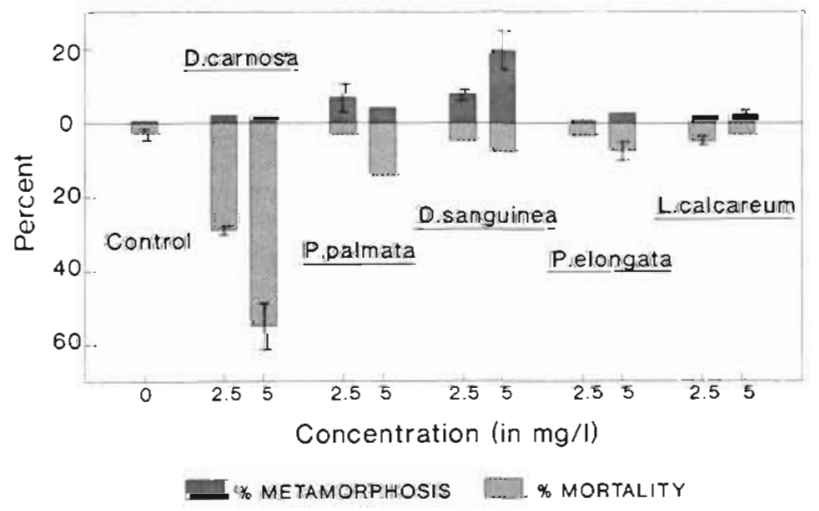

Fig. 1. Pecten maximus. Metamorphosis and mortality rates of larvae induced by aqueous extracts of various red alga species (Dilsea carnosa, Palmaria palmata, Delesseria sanguinea, Polysiphonia elongata, Lithothamnium calcareum). In this and all other figures (unless otherwise mentioned), each value is the mean of 2 replicates, and only standard deviations greater than $\pm 1 \%$ are shown phosis rates for batches treated with $D$. sanguinea $(2.5$ or $5 \mathrm{mg} \mathrm{l}^{-1}$ ) or $P$. palmata $\left(2.5 \mathrm{mg} \mathrm{l}^{-1}\right)$ extracts. All 5 extracts were also toxic, especially that obtained from $D$. carnosa. D. sanguinea extract was the most promising and consequently its study was continued.

\section{Extraction and characterization of metamorphosis- inducing substances from Delesseria sanguinea}

An aqueous EtOH (70\% v/v) extract of Delesseria sanguinea (Extract B) also was able to promote metamorphosis (Fig. 2). After removing most of the EtOH and partitioning the aqueous residue with diethyl ether $\left(\mathrm{Et}_{2} \mathrm{O}\right)$, we obtained an aqueous residue (Extract C) and an ether-soluble fraction (Extract D). The latter displayed higher activity than Extracts $\mathrm{B}$ or $\mathrm{C}$ $\left(F_{15}^{12}=18.47\right)$. Active molecules were consequently more concentrated in Extract D. On the other hand, the toxic effect was also enhanced.

Extract $D$ was divided into 2 fractions ( $E$ and $F$ ) by preparative TLC. Both fractions displayed highly significant activities $\left(F_{6}^{5}=70.48\right)$ which did not differ significantly (Fig. 3). The 6 compounds present in both fractions were purified and tested. Analysis of variance gave significant results $\left(F_{10}^{9}=43.40\right): 4$ compounds ( $\underline{1}$, $\underline{2}, \underline{3 a}$ and $\underline{4}$ ) were able to promote metamorphosis, and 2 compounds $(\underline{3 b}, \underline{5})$ were ineffective (Fig. 4). Compounds 1,2 and $3 a$ were significantly active, but their low activities cannot be compared with those of Fractions $E$ and F. Indeed, only jacaranone 4 displayed an activity compatible with those of Fractions $E$ and $F$. The activity of jacaranone obtained by synthesis was not significantly different from that of naturally occurring jacaranone (Fig. 4). The highest metamorphosis rates

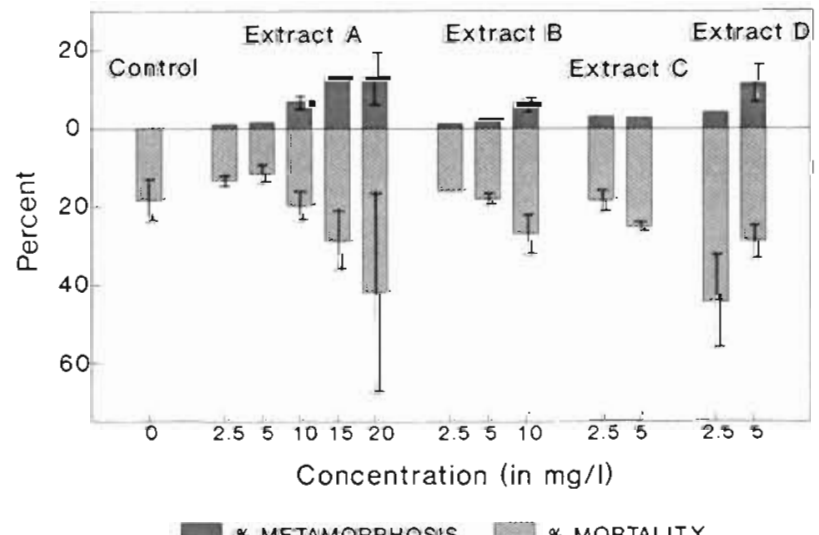

Fig. 2. Pecten maximus. Metamorphosis and mortality rates of larvae induced by various extracts of Delesseria sanguinea: (A) crude aqueous extract; (B) aqueous ethanol extract; (C) aqueous residue after water-diethyl ether partitioning; (D) ether-soluble extract. The control value is the mean of 4 replicates, extracts were tested in duplicate 


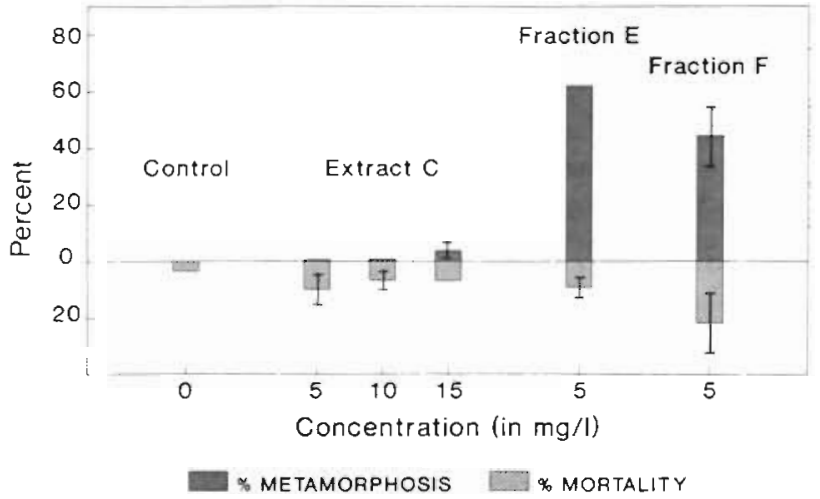

Fig. 3. Pecten Maximus. Effect of Extract $C$ and Fractions $E$ and $F$ on metamorphosis and mortality of larvae

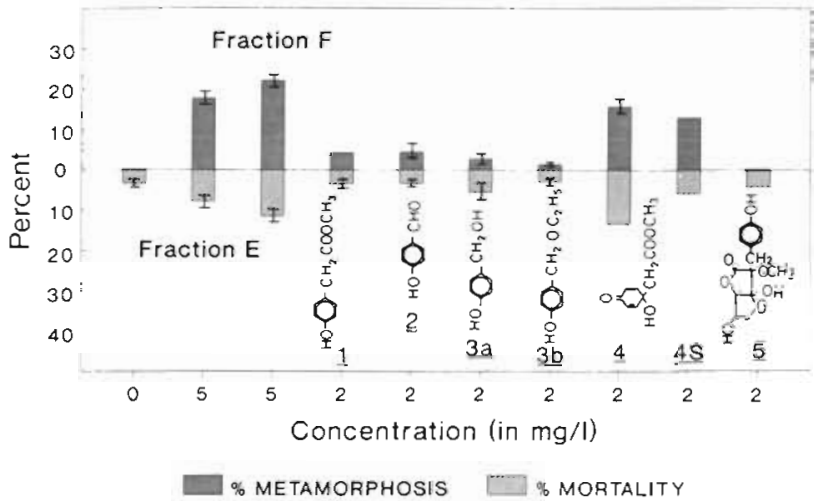

Fig. 4. Pecten maximus. Percentage response of larvae to Fractions $\mathrm{E}$ and $\mathrm{F}, p-\mathrm{OH}$ phenylacetic acid methyl ester $1, p$ $\mathrm{OH}$ benzaldehyde $2, p-\mathrm{OH}$ benzylic alcohol $3 a$ and its ethyl ether $\underline{3 b}$, natural jacaranone $\underline{4}$, synthetic jacaranone $\underline{4} S$ and delesserine $\underline{5}$

were obtained with concentrations in the 0.5 to $1 \mathrm{mg} \mathrm{l}^{-1}$ (3 to $6 \times 10^{-6} \mathrm{M}$ ) range (Fig. 5).

\section{Stimulation of larval metamorphosis by synthetic compounds}

Jacaranone is a methyl ester of quinol acetic acid, an intermediate in the catabolic pathway of tyrosine (Hocart et al. 1983). A possibility existed that jacaranone itself was not a metamorphosis inducer, but rather a precursor of the active compound. To test this hypothesis, the final product (homogentisic acid 6 ) of this biogenic pathway was evaluated in 2 experiments for its ability to promote metamorphosis of Pecten maximus larvae. In the first (Fig 6), conducted under normal light, homogentisic acid $\underline{6}$ showed significant activity $\left(F_{5}^{6}=23.78\right)$, and the highest metamorphosis rates were obtained at a dilution of $10^{-3} \mathrm{~g} \mathrm{l}^{-1}$. It is noteworthy that such a solution of homogentisic acid quickly turned brown (photoxidation to quinone). In the second experiment (Fig. 6), conducted in the dark to slow down oxidation, similar results were obtained $\left(F_{5}^{6}=\right.$ 26.15). Nevertheless, the concentrations required to induce metamorphosis with homogentisic acid are rather higher than with jacaranone. This strongly suggests that jacaranone is active by itself and not as a precursor of homogentisic acid. (In the second experiment, the higher metamorphosis rates observed in controls as well as in treated tanks were due to the fact that larvae were $5 \mathrm{~d}$ older, and so the percentage of competent larvae was higher.)

Activities of jacaranone $\underline{4}$ and homogentisic acid $\underline{6}$ were then compared with those of 3 catecholamines (epinephrine, norepinephrine and L-DOPA) which induce metamorphosis of oyster larvae (see 'Introduction'). In this experiment (Fig. 7), analysis of variance $\left(F_{15}^{14}=23.93\right)$ showed significant activities for epinephrine $\left(10^{-3} \mathrm{~g} \mathrm{l}^{-1}\right)$ jacaranone $\left(5 \times 10^{-4} \mathrm{~g} \mathrm{l}^{-1}\right)$ oxidized homogentisic acid $\left(10^{-3} \mathrm{gl}^{-1}\right)$ and L-DOPA $\left(10^{-3} \mathrm{~g}^{-1}\right)$. but not for unoxidized homogentisic acid. It is note-

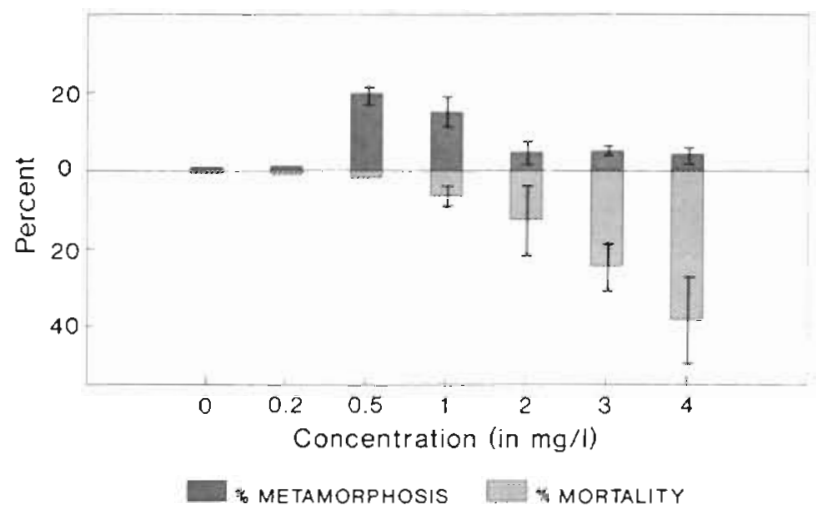

Fig. 5. Pecten maximus. Metamorphosis and mortality of larvae in relation to the concentration of synthetic jacaranone. Each concentration was tested in triplicate

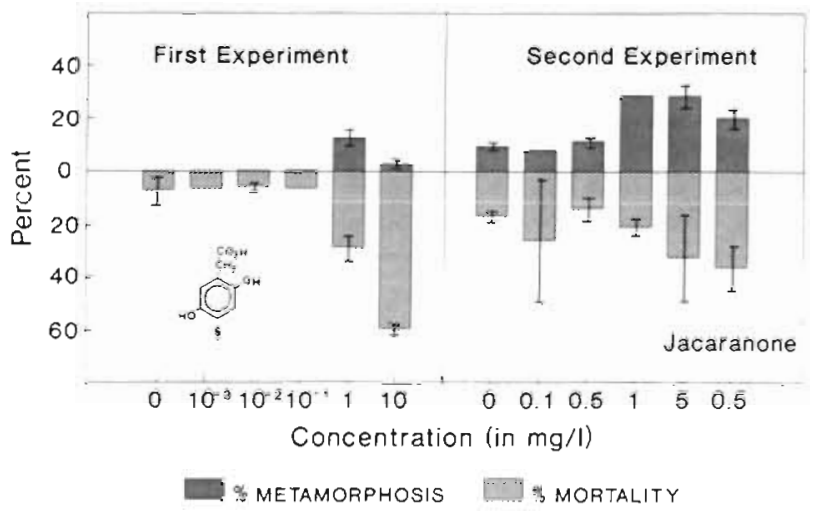

Fig. 6. Pecten maximus. Percentage of metamorphosis and mortality induced by homogentisic acid $\underline{6}$ at various concentrations. The first experiment was conducted under normal light conditions; the second was conducted in the dark (larvae were $5 \mathrm{~d}$ older) 


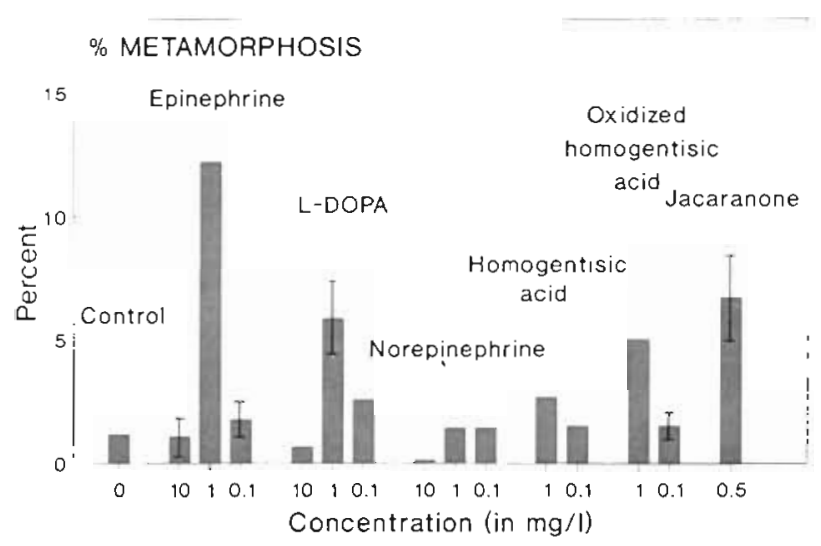

Fig. 7. Pecten maximus. Comparative study of metamorphosis induced by catecholamines, jacaranone and homogentisic acid. The experiment was conducted in the dark. Only standard deviations greater than $0.5 \%$ are shown

worthy that all solutions containing $10^{-3} \mathrm{gl}^{-1}$ (or more) of a hydroquinone changed color, even though the experiment was run in the dark.

\section{DISCUSSION}

In most of our experiments, rates of metamorphosis remained low, and results obtained using the same compound at the same concentration varied greatly from one experiment to another. This is not surprising since metamorphosing larvae require an inducer and must above all be competent. In this study, the method used to sort larvae was not specific for competent larvae. Consequently, the percentage of larvae capable of metamorphosis was often low and also highly variable from batch to batch. Nevertheless, rates of metamorphosis were regularly much higher in the presence of jacaranone than in controls, in the experiments described in this paper as well as in others. Results were more erratic with homogentisic acid.

In the natural environment, larval settlement and metamorphosis of Pecten maximus does not require a specific substratum. In a hatchery, metamorphosis can occur in running seawater but not in still water. A similar observation has been made for the related species Chlamys hastata by Hodgson \& Bourne (1988). According to these authors, larvae metamorphose more readily in the presence of turbulence created by a flow of water. Another explanation could be that a natural inducer is present at low concentration in seawater and that individuals accumulate it until enough is present to trigger metamorphosis [a similar conclusion was drawn by Fitt et al. (1987) for larvae of a cnidarian, Cassiopea andromeda]. In addition, it is also possible that the natural inducer(s) is (are) unstable molecule(s) and that the conditions for production are not fulfilled in hatch- ery conditions, so that it is necessary to renew seawater in hatchery tanks.

Prior to our earlier work (Yvin et al. 1985, Chevolot \& Cochard 1989, Cochard et al. 1989), nothing was known about chemicals able to promote metamorphosis of pectinidae larvae. Hodgson \& Bourne (1988) found that neither GABA nor dopamine are able to enhance the metamorphosis rate of Chlamys hastata larvae and observed only toxic effects at high concentrations. However, for other Pelecypoda there is considerable evidence to show that metamorphosis can be induced by exogenous molecules (see 'Introduction'). It is intriguing that all the presently known inducers (for Pelecypoda) are biosynthetically derived from tyrosine. It is also noteworthy that all of these molecules possess quinone or quinone-like units (melanin from LST bacterium, quinone-tanned proteins of oyster shell periostracum) or can be transformed into quinones by oxidation (catecholamines, phenolic proteins). This feature is also shared by jacaranone (quinol) and homogentisic acid ( $p$-diphenol). Indeed, this latter product is a more powerful inducer when it is (at least partially) oxidized. These observations strongly suggest that the natural inducer(s) is (are) quinone(s) or quinone-like molecule(s). Cooper \& Shaw (1984) also noted that L-DOPA induced more metamorphosis (in larvae of Crassostrea gigas) 'under constant light compared to constant darkness'. This effect could be due to partial oxidation of LDOPA. In contrast, for the polychaete Phragmatopoma lapidosa californica, Pawlik (1990) found that an oxidized DOPA solution is less effective than a fresh one.

Oxidation of epinephrine, norepinephrine or LDOPA can produce several highly reactive forms of reduced oxygen $\left(\mathrm{O}_{2}^{-}, \mathrm{H}_{2} \mathrm{O}_{2}\right.$ ) (Halliwell \& Gutteridge 1986 p. 218) which could be responsible for the toxic action. In seawater, the superoxide anion $\mathrm{O}_{2}^{-}$is a relatively long-lived transient. Petasne \& Zika (1987) calculated a $50 \%$ decay time of $20 \mathrm{~min}$ at a typical steadystate concentration of $10^{-8} \mathrm{M}$. This is a much higher concentration (by a factor of $10^{3}$ to $10^{4}$ ) than inside the cell. Consequently the presence of substances able to generate $\mathrm{O}_{2}^{-}$may be highly deleterious.

In all cases, as a first step of this oxidation process, an intermediate semiquinone radical is produced, so that we have to consider that such long-lived free radicals might be the true metamorphosis inducers, especially since their relative instability fits perfectly with the hypothesis of an unstable metamorphosis inducer (see above). This hypothesis deserves to be considered, all the more because results obtained elsewhere are consistent with it. For instance, Jensen (1987, cited by Pawlik 1990) reported that 'many aromatic analogs of L-DOPA' are able to induce metamorphosis of Phragmatopoma lapidosa, but in a rather erratic manner. 
Among the tested compounds, 2,6-ditertiobutyl-pcresol (known as BHT) gave consistent results. The structures of BHT and L-DOPA are only loosely related, but $\mathrm{BHT}$ is able to trap reactive free radicals to form a more persistent radical (Lowry \& Richardson 1981); this is the reason of its use as an antioxidant. A similar property is also expected from $\delta$-tocotrienols (analogs of tocopherols, a group of natural antioxidants), the substances which induce metamorphosis of Coryne uchidai (hydrozoa) and which are isolated from Sargassum tortile (Kato et al. 1975). In all cases, these metamorphosis inducers (catecholamines, BHT, $\delta$-tocotrienols) are able to generate long-lived free radicals

Coon et al. (1985, 1988) proposed a settlement and metamorphosis model. As a first step, competent larvae are induced to settle by an exogenous 'L-DOPA mimetic molecule'. The release of endogenous catecholamines (the second step) induces the beginning of metamorphosis. These authors provided subsequent further evidence showing that metamorphosis is mediated through adrenoreceptors (Coon \& Bonar 1987). The second step of the model now seems to be wellestablished, but we feel that the nature of the triggering entities in the first step is still uncertain.

Acknowledgements. The authors thank Mrs L. Stawecki for typing the manuscript and for her patience.

\section{LITERATURE CITED}

Brand, A. R., Paul, J. P., Hoogesteger, J. N. (1980). Spat settlement of the scallops Chlamys opercularis (L.) and Pecten maximus (L.) on artificial collectors. J. mar. biol. Ass. U.K. $60: 379-390$

Buestel, D., Cochard, J. C., Dao, J. C., Gerard, A. (1982) Production artificielle de naissain de coquilles Saint Jacques Pecten maximus (L.): premiers résultats en rade de Brest. Vie mar. 4: 24-28

Burke, R. D. (1983). The induction of metamorphosis of marine invertebrate larvae: stimulus and response. Can. J. Zool 61: $1701-1719$

Chevolot, L., Cochard, J. C. (1989). Tyrosine metabolites as metamorphosis inducers of Pecten maximus larvae: on the path to the true inducers. In: Miyachi, S., Karube, I., Ishida, Y (eds.) Current topics in marine biotechnology. Proceedings of the First International Marine Biotechnology Conference, Tokyo, Sep 3-6, 1989. Japanese Society for Marine Biotechnology, Tokyo, p. 407-410

Cochard, J. C., Chevolot, L., Yvin, J. C., Chevolot-Magueur, A. M. (1989). Induction de la métamorphose de la coqulle Saint-Jacques Pecten maximus (L. ) par des dérivés de la tyrosine extraits de lalgue Delesseria sanguinea (Lamouroux) ou synthétiques. Haliotis 19: 129-154

Coon, S. L., Bonar, D. B. (1987). Parmacological evidence that a1-adrenoreceptors mediate metamorphosis of the Pacific oyster Crassostrea gigas. Neurosci. 23 (3): 1169-1174

Coon, S. L., Bonar, D. B., Fitt, W (1988). An integrated model of oyster settlement and metamorphosis. J. Shellfish Res. 7 (3): $548-549$
Coon, S. L., Bonar, D. B., Weiner, R. M. (1985). Induction of settlement and metamorphosis of the Pacific oyster, Crassostrea gigas (Thunberg), by L-DOPA and catecholamines. J. exp. mar Biol. Ecol. 94: 211-221

Coon, S. L., Bonar, D. B., Weiner, R. M. (1986). Chemical production of cultchless oyster spat using epinephrine and norepinephrine. Aquaculture 58: 255-262

Cooper, K. (1982). A model to explain the induction of settlement and metamorphosis of planktonic eyed-pediveligers of the blue mussel Mytilus edulis (L.) by chemical and tactile cues. J. Shellfish Res. 2: 117

Cooper, K. L., Shaw, W N. (1984). The effects of environmental factors in the ability of chemical cues to trigger settlement and metamorphosis of the Pacific oyster Crassostrea gigas. J. Shellfish Res. 4 (1): 85-86

Crisp, D. J. (1967). Chemical factors inducing settlement in Crassostrea virginica (Gmelin). J. Anim. Ecol. 36: 329-335

Crisp, D. J. (1984). Overview of research on marine invertebrate larvae 1940-1980. In: Costlow, J. D., Tipper, R. C. (eds.) 'Marine biodeterioration: an interdisciplinary study'. Naval Inst. Press, Annapolis, p. 103-126

Estupinan, B., Waite, J. H. (1988). Induction of settlement and metamorphosis of Mytilus edulis (L.) larvae by DOPAcontaining polyphenolic protein. J. Shellfish Res. $7(1)$ : 189-190

Fitt, W K., Hofmann, D. K., Wolk, M., Rahat, M. (1987). Requirement of exogenous inducers for metamorphosis of axenic larvae and buds of Cassiopea andromeda (Cnidaria: Scyphozoa). Mar. Biol. 94: 415-422

Gruffydd, L. D., Beaumont, A. R. (1972). A method for rearing Pecten maximus larvae in the laboratory. Mar. Biol. 15: 350-355

Hadfield, M. G. (1986). Settlement and recruitment of marine invertebrates: a perspective and some proposals. Bull. mar. Sci. 39 (2) : 418-425

Halliwell, B., Gutteridge, J. M. C. (1986). Free radicals and toxicology, Chap. 6. In: 'Free radicals in biology and medicine' Clarendon Press, Oxford, p. 206-243

Hirata, K. Y. Hadfield, M. G. (1986). The role of choline in metamorphic induction of Phestilla (Gastropoda, Nudibranchia). Comp. Biochem. Physiol 84C: 15-21

Hocart, C. H., Halpern, B., Hick, L. A., Wong, C. O., Hammond, J. W., Wilcken, B. (1983). Hawkinsinuria-identification of quinolacetic acid and pyroglutamic acid during an acidotic phase. J. Chromatogr. 275: 237-243

Hodgson, C. A., Bourne, N. (1988). Effect of temperature on larval development of the spiny scallop Chlamys hastata Sowerby, with a note on metamorphosis. J. Shellfish Res. 7 (3): $349-357$

Kato, I., Kumanireng, A. J., Ichinose, I, Kitahara, Y, Kakinuma, Y., Nishihira, M., Kato, M. (1975). Active components of Sargassum tortile affecting the settlement of swimming larvae of Coryne uchidai. Experientia 31 (4): 433-434

Keck, R., Maurer, D., Kauer, J. C., Sheppard, W A. (1971) Chemical stimulants affecting larval settlement in the American oyster. Proc. natn. Shellfish Ass. 61 24-28

Loosanoff, V L., Davis, H. C. (1963). Rearing of bivalve molIuscs. Adv. mar. Biol. 1. 2-136

Lowry, T H., Richardson, K. S. (1981). Mechanism and theory in organic chemistry, 2nd edn. Harper and Row, New York, p. 714-716

Minchin, D. (1981). The escallop Pecten maximus in Mulroy Bay. Fish. Bull. (Dublin) 1: 1-21

Morse, A. N. C., Morse, D. E. (1984). Recruitment and metamorphosis of Haliotis larvae induced by molecules uniquely available at the surfaces of crustose red algae. J exp. mar Biol. Ecol. 75; 191-215 
Morse, D. E. (1985). Neurotransmitter-mimetic inducers of larval settlement and metamorphosis. Bull. mar. Sci., 37 (2): $697-706$

Morse, D. E. (1990). Recent progress in larval settlement and metamorphosis: closing the gaps between molecular biology and ecology. Bull. mar. Sci. 46 (2): 465-483

Nell, J. A., Holliday, J. E. (1986). Effects of potassium and copper on the settling rate of Sydney rock oysters (Saccostrea commercialis) larvae. Aquaculture 58 (3-4): 263-267

Nielsen, S. A. (1973). Effect of acetazolamide on larval settlement of Ostrea lutaria. The Veliger 16 (1): 66-67

Pawlik, J. R. (1986). Chemical induction of larval settlement and metamorphosis in the reef-building tube worm Phragmatopoma californica (Polychaeta: Sabellariidae). Mar. Biol. 91: 59-68

Pawlik, J. R. (1990). Natural and artificial induction of metamorphosis of Phragmatopoma lapidosa californica with a critical look at the effects of bioactive compounds on marine invertebrate larvae. Bull. mar. Sci. 46 (2): $512-536$

Petasne, R. G., Zika, R. G. (1987). Fate of superoxide in coastal sea water. Nature, Lond. 325: 516-518

This article was submitted to the editor
Snedecor, G. W., Cochran, W. G. (1967). Statistical methods, 6 th edn. Iowa Univ. Press, Ames

Weiner, R. M., Colwell, R. R. (1982). Induction of settlement and metamorphosis in Crassostrea virginica by a melaninsynthesising bacterium. Tech. Rep. Maryland Sea Grant Prog., Publ. U.M. S.G. T.S. 82-05, 44 p.

Weiner, R. M., Segall, A. M., Colwell, R. R. (1985). Characterization of a marne bacterium associated with Crassostrea virginica (The Eastern Oyster). Appl. environ. Microbiol. 49: 83-90

Yool, A. J., Grau, S. M., Hadfield, M. G., Jensen, R. A., Markell, D. A., Morse, D. E. (1986). Excess potassium induces metamorphosis in four invertebrates species. Biol. Bull. mar. biol. Lab., Woods Hole 170 (2): 255-266

Yvin, J. C., Chevolot-Magueur, A. M., Chevolot, L., Lallemand, J. Y., Potier, P., Guilhem, J. (1982). Delesserine, a new metabolite of mixed biogenesis from the red marine Alga Delesseria sanguinea (Lamouroux). J. Am. Chem. Soc. $104: 4497$

Yvin, J. C., Chevolot, L., Chevolot-Magueur, A. M., Cochard, J. C. (1985). First isolation of jacaranone from an alga Delesseria sanguinea: a metamorphosis inducer of Pecten larvae. J. nat. Prod. 48: 814-816

Manuscript first received: January 14, 1991

Revised version accepted: April 25, 1991 